\title{
STROKOVNE PODLAGE V REGIONALNEM IN PROSTORSKEM PLANIRANJU
}

\section{Ljubljana, II. II. 2010}

Oddelek za geografijo Filozofske fakultete Univerze v Ljubljani in Zveza geografov Slovenije sta 11. novembra $2010 \mathrm{v}$ prostorih Filozofske fakultete v Ljubljani organizirala okroglo mizo z naslovom Strokovne podlage v regionalnem in prostorskem planiranju. Njen namen je bil odpreti strokovna vprašanja na planerskem področju ter oblikovati skupna strokovna izhodišča različnih strok, ki so vključene v proces planiranja. Z njimi bi prispevali k reševanju odprtih vprašanj, do katerih prihaja ob preučevanju predmeta regionalnega in prostorskega planiranja.

Okrogla miza je bila posvečena 80-letnici akademika prof. dr. Igorja Vrišerja, ki je bil vodilni raziskovalec in univerzitetni pedagog s področja priprave strokovnih podlag in oblikovanja prostorskega in regionalnega planiranja v Sloveniji ter avtor edinega učbenika o regionalnem planiranju v slovenskem jeziku.

Po uvodnem pozdravu prodekana Filozofske fakultete prof. dr. Andreja Černeta, ki je na kratko orisal vlogo prof. Vrišerja pri razvoju regionalnega in prostorskega planiranja $\mathrm{V}$ Sloveniji in predstavil namen okrogle mize, sta udeležence nagovorila tudi predstavnika organizatorjev srečanja. Predstojnik Oddelka za geografijo Filozofske fakultete Univerze v Ljubljani prof. dr. Jernej Zupančič je poudaril, da je prostor vezni člen med različnimi strokami, zato je vse prisotne povabil, da si skupaj prizadevajo za večjo vlogo prostora pri sprejemanju razvojnih odločitev. V imenu Zveze geografov Slovenije je prisotne nagovoril prof. dr. Darko Ogrin.

Uvodnemu delu so sledile predstavitve vabljenih predstavnikov stanovskih društev in zvez, ki so še posebej dejavni pri strokovnih dejavnostih, povezanih s planiranjem.

Dr. Marjan Ravbar (Zveza geografov Slovenije) je izpostavil nekatere izzive, s katerimi se sooča planiranje v Sloveniji. Izpostavil je neučinkovitost vztrajanja na policentričnem sistemu, saj naj bi nove teoretične predpostavke, planerska praksa, stanje v prostoru in sodobni razvojni izzivi zahtevali oblikovanje drugačnega pristopa k prostorskemu in regionalnemu planiranju. Opozoril je tudi na dualnost prostorskega in razvojnega načrtovanja, ki pa bi ga bilo mogoče preseči z regionalnim menedžmentom. Po njegovem mnenju bi morala ekonomska in regionalna politika v večji meri upoštevati pokrajinsko raznolikost Slovenije.

Po predstavitvi dr. Marjana Ravbarja je doc. dr. Simon Kušar predstavil sklepe in priporočila Zveze geografov Slovenije, ki so bili sprejeti na podobnem strokovnem srečanju marca 2010:

- presoje vplivov načrtovanih investicij na okolje je potrebno nadgraditi s presojo vplivov na prostor oziroma pokrajino;

- sektorske politike naj se prav tako vrednoti z vidika njihovih vplivov na prostor;

- zaradi pokrajinske raznolikosti Slovenije je potreben regionalen pristop k planiranju;

- planiranje 'na parcelo natančno' mora biti dopolnjeno s celovitim in kompleksnim pogledom na prostor; 
- potrebno je ponovno vzpostaviti celovit sistem regionalnega planiranja;

- v planiranju morajo imeti večjo vlogo projekcije prihodnjih potreb po rabi prostora;

- evropski pravni red naj se bolj celovito vključi v pravni red Republike Slovenije in v sistem planiranja;

- posegi v prostor naj bodo vrednoteni iz različnih kriterijev (estetski, doživljajske zmožnosti prebivalcev).

Sledila je predstavitev dr. Aleša Mlakarja (Društvo krajinskih arhitektov Slovenije). V njej je izpostavil vlogo regionalne ravni prostorskega načrtovanja. Strokovne podlage na regionalni ravni lahko pripomorejo k povezovanju strateških razvojnih usmeritev na državni ravni in podrobnejšega prostorskega planiranja na lokalni ravni. Strokovne podlage morajo biti problemsko naravnave in usmerjene v zbiranje tistih informacij, ki služijo oblikovanju in optimizaciji prostorskih rešitev. Zagotavljati morajo informacije $\mathrm{z}$ vrednostnim razponom ter omogočati tehtanje prostorskih odločitev in usklajevanje interesov v prostoru. Dr. Mlakar je za učinkovito razrešitev dilem, s katerimi se srečujeta regionalno in prostorsko planiranje v Sloveniji, izpostavil vlogo šestih sklepov, ki so bili izoblikovani v pozivu za spremembe v urejanju prostora v okviru projekta 'Odgovorno do prostora'.

Prof. dr. Andrej Pogačnik (Društvo urbanistov in prostorskih planerjev Slovenije) je opozoril, da so bolj kot nove strokovne podlage potrebne metode, tehnike, koncepti in primeri dobrih praks, ki vodijo k sintezi, potrebni za oblikovanje prostorskega plana. Predavatelj je nanizal tudi številne ideje, kako bi lahko z regionalnimi analizami prispevali k večjemu vedenju o prostoru, kar bi pomembno izboljšalo pripravo strokovnih podlag, potrebnih za sprejem odločitev o razvoju v prostoru. Kakovostna regionalna analiza lahko odgovori na vprašanja, povezana z optimalno lokacijo gospodarskih parkov in oblikovanjem regionalnih turističnih proizvodov, prispeva $\mathrm{k}$ boljšemu poznavanju razvojnih potencialov regij in značilnih regionalnih prostorskih vzorcev ter pomaga pri razvoju manj razvitih območij ali upravljanju s povodji.

Jože Kos Grabar (Zveza geodetov Slovenije) je naštel številne dileme, s katerimi se srečuje planiranje: zadrege so pri strokovni terminologiji, premalo se posveča velikim razvojnim projektom, na voljo je premalo planerskih metod, obstajajo metodološke in tehnične težave s prostorskimi podlagami. Predavatelj je izpostavil, da je potrebna integracija znanj, saj morajo strokovnjaki iz različnih področij dobro razumeti različne vidike načrtovanja. Po njegovem mnenju je potrebno spodbuditi sodelovanje med izobraževalno sfero in planerskimi podjetji, tudi z aplikacijo planerskih metod, razvitih $\mathrm{v}$ akademski sferi.

$\mathrm{Na}$ podlagi uvodnih predstavitev in razprave so bili izoblikovani naslednji predlogi za spremembe in prihodnji razvoj, tako na področju izdelave strokovnih podlag v regionalnem in prostorskem planiranju kot tudi za spremembe $\mathrm{v}$ sistemu regionalnega in prostorskega planiranja v Sloveniji:

- integriranje razvojnega in prostorskega planiranja;

- ponovno uvedbo prostorskega planiranja na regionalni ravni;

- publiciranje že pripravljenega planerskega terminološkega slovarja;

- spodbujanje prenosa že uveljavljenih in novih planerskih metod in pristopov v prakso; 
- tesnejše povezovanje izobraževalnih in raziskovalnih organizacij s podjetji, ki pripravljajo strokovne planerske podlage in prostorske dokumente;

- spodbujanje interdisciplinarnega in medinstitucionalnega sodelovanja pri pripravi strokovnih planerskih podlag;

- oblikovanje kakovostnih interdisciplinarnih raziskovalnih in projektnih skupin;

- prizadevanje za povečanje vloge prostora v družbi;

- izobraževanje politike, uprave in širše javnosti o vlogi strokovnih podlag ter regionalnega in prostorskega planiranja.

Razprava in sklepi okrogle mize so namenjeni spodbujanju dialoga in širšim strokovnim razpravam o aktivnem vključevanju regionalnega in prostorskega planiranja pri sprejemanju odločitev o prihodnjem razvoju Slovenije ter prispevek k ciljem projekta 'Odgovorno do prostora'.

Več informacij o okrogli mizi in teze uvodnih predavateljev je mogoče najti na spletnih straneh Oddelka za geografijo Filozofske fakultete Univerze v Ljubljani (http:/geo.ff.unilj.si/).

Dogodek podpira projekt 'Odgovorno do prostora'!

Simon Kušar 